\title{
IgM-IgG-IgA Secondary Mixed Cryoglobulinemia Associated with Paediatric Tonsillitis
}

\author{
Jassim Yazi Abdulla \\ Department of Biology, College of Science, University of Babylon, Hilla, Iraq \\ Email address: \\ yaziabdalla2014@gmail.com \\ To cite this article: \\ Jassim Yazi Abdulla. IgM-IgG-IgA Secondary Mixed Cryoglobulinemia Associated with Pediatric Tonsillitis. American Journal of \\ Biomedical and Life Sciences. Advances in Oral Immunity. Vol. 3, No. 4-1, 2015, pp. 10-12. doi: 10.11648/j.ajbls.s.2015030401.14
}

\begin{abstract}
A cryoprotein was separated from sera of the pediatric tonsillitis patients. Such protein characterized as: percipitable at $4 \mathrm{c}$, dissolvable at $37 \mathrm{c}$ and repercipitable at $4 \mathrm{c}$. It showed gelatinous or crystalline texture. The immunochemical quantitation using single radial immune diffusion for immunoglobulin isotypes revealed mixed IgM-IgG-IgA isotypes. Hence secondary mixed cryoglobulinemia type III was proven in association with pediatric tonsillitis rate of 29:30(96.66\%).
\end{abstract}

Keywords: Cryglobulin, Mixed Cryglobulinemia, Paediatric, Sera, Texture

\section{Introduction}

Tonsils are lymphoid glandular compartments that stands as a part of the common mucosal immune system which denoted as by: welder wring ${ }^{[1.2]}$ They are located in human stomium and acts as safe-guard of food, drink and suck born pathogens $\left[{ }^{3}\right]$. Tonsillitis is a state of tonsillar infection occurred when the invading overwhelming pathogen load, gain food hold and seeded within these lymphoid tissue $\left[{ }^{3]}\right.$. Such seeded infectious pathogens when they becomes in rather meaningful population size started quarum sensing communication producing virulence factors $\left[{ }^{4}\right]$. Where in intact subunits secretion protein toxin and/or the immune consequences in single or collective initiated the inflammatory responses $\left[^{5}\right]$. During infectious processes and then after, hypersensitivity and/or autoimmune besides the immune responses may follow the inflammatory responses ${ }^{[6]}$. Among the most often occurred consequences of tonsillitis is the rheumatic autoimmune responses initiated by molecular memicating epitopes of the pathogens and joint and/or heart tissue epitopes $\left.{ }^{7}\right]$. Such situation made host vulnerable to cryoglobulin responses $\left[{ }^{8}\right]$. The present work was undertaken to map the possible cryoglobulin responses among childhood tonsillitis.

\section{Main Body}

Thirty clinically proven tonsillitis in paediatric patients $\left[{ }^{9}\right]$. the patients complained fever, headache, vomition, swelling and tender in the tonsiller region with an apparent difficulty in swelling food and drinks, rise up of acute phase protein $\mathrm{C}$ stands as a confirmation for bacterial inflammation. The age range were from 6-12 years old ,Table 1 .Ten apparently normal child of age group matching to that of patients were considered as controls. Five mls blood samples without anticoagulants were collected both from patients and controls Sera were obtained and saved in $0.5 \mathrm{ml}$ aliquots at $18 \mathrm{C}[10]$.The cryoglobulin responses were detected using Lynch [11],criteria ,including, precipitation within seven days at $4 \mathrm{C}$,crystalline or gelatinous textures, dissolved at $37 \mathrm{C}$ or $45 \mathrm{C}$ then reprecipitated on reincubation at $4 \mathrm{C}$ and being positive in biurt test Table 2 .The cryglobulin preparations were isotyped using single radial immunodiffusion in gel containing anti-IgG,Anti-IgM,IgA from ready makes ,concentration of immunoglobulins were determined in comparison with standard concentration tables provided by manufacturer instruction leaflet[12].

Table 1. Childhood tonsillitis patients characteristics.

\begin{tabular}{ll}
\hline Age: $\mathbf{6}-\mathbf{1 2}$ years \\
\hline Age group distribution: & Number of patients \\
6 years & 9 \\
9 years & 10 \\
12 years & 12 \\
Total & 29 \\
Sex: Male to female ratio & $1.2 / 1$ \\
Disease Duration; few days, concurrent, chronic \\
Signs and Symptoms ; Fever \\
\multicolumn{2}{c}{ Joint pain } \\
\hline
\end{tabular}




\begin{tabular}{ll}
\hline Age: 6 - 12 years & Swallowing difficulty \\
Vomition & Tender and pain in the neck area \\
& \\
Fallow up and diagnostic, Acute Phase protein C is clinically significant \\
titre and concentration \\
$\begin{array}{l}\text { Titre Range: } 4 \text { to } 12 \\
\text { Concentration Range: } 28 \text { to } 65 \mathrm{mg} / \mathrm{ml}\end{array}$ \\
\hline
\end{tabular}

Table 2. The research oriented modification of Lynch 2006(11) basic criteria for cryoglobulin determinations in child hood tonsillitis sera.

-Sample bottoles should be heated to and maintained at $40 \mathrm{C}$ prior to venopuncture

- Five mls. Of blood collected into red-tapped clotted sample tubes

-Samples must be transported to the laboratory at 40C and must not allowed to fall below $3 \&$ C. Samples arrived below $37 \mathrm{C}$ should be rejected.

-Samples should be allowed to clot at least at $37 \mathrm{C}$ for two hours

-Samples should be centrifuged at $37 \mathrm{C}$ for $5 \mathrm{~min}$. at $1500 \mathrm{~g}$

- Serum Samples should be incubated at $4 \mathrm{C}$

-The incubated serum samples should be observed daily up to 7 days

-Any precipitates or gels must be re solubilized at $37 \mathrm{C}$

-All positive samples for cryglobulin must be quantified using standard total protein method

-Cryglobulin should b e washed at least five times with ice cold normal saline or phosphate buffer saline before immunofixation

\section{Results and Discussion}

The 29 tonsillitis patients serum samples were showing cryoprecipitates when incubated at $4 \mathrm{c}$ for up to seven days their nature were either gelatinous or crystalline with milky or creamy white colors. The test serum samples were showing cryocrit percentage ranged from 1.2-17.5\% 1 (A) Table .The cryoprecipitates were of protein nature by the virtue of being positive in biurt test. Their ranges were between $23-55 \mathrm{mg} / \mathrm{ml}$. while the man concentration ratio was $34.808 \mathrm{mg} / \mathrm{ml}$ Table 1 (C)The concentration of CRP were ranging between $12 \& 96$ and with a mean of $40.6 \mathrm{mg} / \mathrm{ml}$ while the titers were ranging between 2-16 with a mean of 6.9Table 1 (D).The obtained cryoglobulin preparation were precipitated at $4 \mathrm{c}$, dissolved at $37 \mathrm{c}$ and reprecipitate The immunofixation studies done on the cryoglobulin preparations were found $\operatorname{IgM}$ concentration of 0.745 to 3.977 , $\mathrm{IgG}$ concentration ranging from 0.448 to 28.049 and $\mathrm{IgA}$ concentration ranging from 0.334 to $4.767 \mathrm{mg} / \mathrm{ml}$. while the mean concentration were $2.3015,15.1041,2.8619 \mathrm{mg} / \mathrm{ml}$ for IgM, IgG, IgA respectively Table 2 controls were negative for cryoglobulin studies

Table 3. Assessment of cryoglobulin response in childhood tonsillitis patient.

\begin{tabular}{ll}
\hline A/ cryocrite percent & \\
\hline Features & Percentages \\
\hline Mean & 8.04 \\
Median & 9.4 \\
Range & $1.2-17.3$ \\
B/Dissolving time & \\
Mean & 1.45 hours \\
Median & 1.5 hours \\
Range & $1.15-2.80$ \\
C/ protein concentration & \\
Mean & $34.808 \mathrm{mg} / \mathrm{ml}$ \\
Median & $29 \mathrm{mg} / \mathrm{ml}$ \\
\hline
\end{tabular}

\begin{tabular}{lll}
\hline A/ cryocrite percent & & \\
\hline Features & Percentages & \\
\hline C/Range & $20.5-55.6$ & \\
D/Acute phase protein response & & \\
& Titer & $\mathrm{Mg} / \mathrm{ml}$ \\
Mean & 6.9 & 40.6 \\
Median & 4.0 & 40 \\
Range & $2-16$ & $6-96$ \\
\hline
\end{tabular}

Table 4. Tonsillitis patients cryoglobulin isotypes.

\begin{tabular}{llll}
\hline \multirow{2}{*}{ Features } & \multicolumn{2}{l}{ Concentration } & \\
\cline { 2 - 4 } & IgM & IgG & IgA \\
\hline Mean & 2.3015 & 15.1041 & 2.8619 \\
Median & 2.882 & 18.040 & 3.036 \\
Range & $0.745-3977$ & $11.117-28.049$ & $0.334-4.767$ \\
\hline
\end{tabular}

Cryoglobulin responses among pediatric tonsillitis patients Table1 and 2 are being reported. The possible immune potential of tonsil invading pathogens may stimulate normoglobulin response both at muscosal compartment and systemic level $\left[{ }^{13}\right]$, as well as cryoglobulin responses Table 3 and 4. The epitope inducing the normoglobulin responses may be the same as that induce cryoglobulin responses and/ or there might be presence of cryo -acting B-cell clones that respond well to cryo inducing other epitope $(s)\left[{ }^{14,19}\right]$. Based on these findings Table 3 and 4 and on the explanatory assumptions $\left.{ }^{[14,19}\right]$, tonsillar inflammations were showing secondary mixed cryoglobulinemia type $\mathrm{III}\left[{ }^{8}\right]$ which composed of the isotypes $\operatorname{IgM-IgG-IgA~Table~4.~In~this~}$ province, Shanawa and his colleagues have been reported cryoglobulin responses in tuberculosis $\left[{ }^{14,15}\right]$ typhoid $\left[{ }^{16}\right]$ and brucellosis $^{[17]}$ and tuberculosis experimentally in rabbits $\left[{ }^{18}\right]$,Table 5 . Thus, tonsillitis, type III secondary mixed cryoglobulinemia are being reported.

Table 5. Comparative view to the bacterial infection associated cryglobulinemia in this area.

\begin{tabular}{ll}
\hline Infectious disease & Nature of cryglobulinemia \\
\hline Tuberculosis & Secondary mixed, of IgM-IgG-IgA type(14) \\
\hline Geriatric tuberculosis & $\begin{array}{l}\text { Secondary mixed of IgM-IgG-IgA type, lower } \\
\text { in concentration than tuberculus young(15) }\end{array}$ \\
Typhoid & Secondary mixed of IgM-IgG-IgA type(16) \\
Brucellosis & Secondary mixed of IgM-IgG and IgM-IgG- \\
This study childhood & IgA types (17) \\
tonsillitis & Secondary mixed of IgM-IgG-IgA type \\
\hline
\end{tabular}

\section{Conclusion}

i. Cryoglobulin response is being reported in pediatric tonsillitis patients.

ii. Pediatric tonsillitis associated cryoglobulinemia is of mixed secondary type and may be classified as type III

\section{Acknowledgements}

The author wish to thank the clinicians whom diagnose tonsillitis patients at Gebella district/Babylon province 


\section{References}

[1] Brandatzaeg P. 1994. Hand book of mucosal Immunology, San Diego, Academic press.

[2] Parslow TG. ,Stites D.P., Terr AI., Imboden TB. Medical immunology $10^{\text {th }}$ edlang medical publications New York.

[3] Brooks GF., Carrol KC .,Butel JS., Morse SA \&Mietzner TA. 2013. Jawetz, Melnick and Adelbergs Medical microbiology $26^{\text {th }}$ ed . Lang Mc Grow Hill N.Y.

[4] Williams P., Camara M., Hardman A., Swift S.,Milton D., Hope VJ., Winzer K., Middlton B., Pritchard DI ,Bycrofl BW. 2002. Quarum sensing and population dependent control of virulence. Phil. Trans . Roy. Soc. Lond B 355, 664-680.

[5] Paul W. 2008. Fundamental Immunology $10^{\text {th }}$ ed Walter Kluwer Williums and Wilkins.

[6] Delves PJ., Martin SJ., Burton DR. and Roitt I M.2006. Essential Immunology $11^{\text {th }}$ ed Black well publishing U.S.A.

[7] Bashir S. F.2009. Text book of Immunology Eastern, Economy Edition PHI, India.

[8] Dispenzieri A., and Gorevic P. 1999. Cryoglobulinemia. Hacmatol. Oncol. Clin. North. Am. 13(6): 1315-1345.

[9] Gillies R.R. 1984. Gillies and Dodds Bacteriology Illustrated $5^{\text {th }}$ ed. Churchill-living stone, 115 .

[10] Samaranayake LP. And Jones BM 2002.Essential microbiology for dentistry $2^{\text {nd }}$ edhurrchill - living stone London 151-158.

[11] Lynch PLM.2006. Audit of cryoglobulin determination in north Irland. Clinical biochemistry department full implementation of all new guide lines.

[12] Mancini G., Carbonara AO., Heremans JF. 1965. Immunochemical quantitation of antigens by single radial immunodiffusion. Immunochem. 2: 235-245.

[13] Shnawa IMS and AL Amidi BHH. 2009. Immune status of tonsillitis patients. College of science. $4^{\text {th }}$. Conf. Vol.4: 239243.

[14] Shnawa IMS. And AL Gebori NRR 2012.Secretory and circulatory cryoglobulinemia in pulmonary tuberculosis patients Baby. Uni. J. 20(5): 1415-1422.

[15] Shanawa IMS. and AL Garani EFH. 2014. The effect of aging on cryoglobulin responses in pulmonary tuberculosis patients Baby. Uni. 22(1): 738-148.

[16] Shnawa IMS. and Al Serhan AJ 2014.Mixed IgG, IgM and IgA cryoglobulin response in human Typhoid patients, IOSRJ. Pharm. Biolo. Sci. 4(2):26-29.

[17] Shnawa IMS. and Jassim Y.A.2014. Mixed two variant types of cryoglobulinemia associated with brucellosis human patients WJPR,3(4):1883-1889.

[18] Shnawa IMS. and Jassim Y.A.2011. BCG and Tuberculin induced experimental lapin secondary cryoglobulinemia $Q M J$ 7(12): 209-219. 